\title{
Context for Understanding the National Demonstration Project and the Patient- Centered Medical Home
}

\author{
Kurt C. Stange, $M D, P b D$ \\ William L. Miller, MD, MA \\ Paul A. Nutting, MD, MSPH \\ Benjamin F. Crabtree, $P b D$ \\ Elizabeth E. Stewart, PbD \\ Carlos Roberto Jaén, MD, PbD

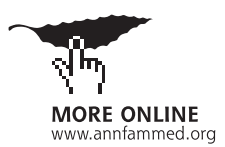

Conflicts of interest: The authors' funding partially supports their time devoted to the evaluation, but they bave no financial stake in the outcome. The authors' agreement with the funders gives them complete independence in conducting the evaluation and allows them to publisb the findings without prior review by the funders. The authors bave full access to and control of study data. The funders bad no role in writing or submitting the manuscript.

\section{CORRESPONDING AUTHOR}

Kurt C. Stange, MD, PhD

Case Western Reserve University

10900 Euclid Ave, LC 7136

Cleveland, $\mathrm{OH} 44106$

kcs@case.edu

\begin{abstract}
This article introduces a journal supplement evaluating the country's first national demonstration of the patient-centered medical home (PCMH) concept. The $\mathrm{PCMH}$ is touted by some as a linchpin for renewing the foundering US health care system and its primary care foundation.

The National Demonstration Project (NDP) tested a new model of care and compared facilitated and self-directed implementation approaches in a grouprandomized clinical trial. The NDP asked what a national sample of 36 highly motivated family practices could accomplish in moving toward the PCMH ideal during 2 years within the current US health care payment and organizational system. Our independent evaluation used a multimethod approach that integrated qualitative methods to tell the NDP story from multiple perspectives and quantitative methods to assess and compare aspects that could be measured. The 7 scientific reports presented in this supplement explain the process, outcomes, lessons, and implications of the NDP.

This introductory article provides context for making sense of the NDP. Important context includes the evolution of the PCMH concept and movement, the roots of the NDP and how it developed, and both what is valuable and what is problematic about family medicine and primary care.

Together, the articles in this supplement show how primary care practices and the concept of the PCMH can continue to evolve. The evaluation depicts some of the early effects of this evolution on patients and practices, and shows how the process of practice development can be understood and how lessons from the NDP can inform ongoing and future efforts to transform primary care and health care systems.
\end{abstract}

Ann Fam Med 2010;8(Suppl 1):s2-s8. doi:10.1370/afm.1110

\section{INTRODUCTION}

7 his article and the journal supplement it introduces are about the promise of primary care, the growing frustrations of not meeting that promise, and the strategies recently envisioned to try to rediscover the lost promise. The supplement, which follows up on an earlier report, ${ }^{1}$ weaves together different threads about one recent particular part of the story, the implementation and evaluation of the National Demonstration Project (NDP) of the patient-centered medical home (PCMH).

\section{SEVEN REPORTS THAT TOGETHER TELL A STORY}

The NDP tested a new model of care and compared facilitated and selfdirected approaches to implementing this model in a group-randomized clinical trial. The NDP asked what a national sample of 36 highly motivated family practices could accomplish in moving toward the PCMH ideal during 2 years within the current US health care payment and organizational system. The project was independently evaluated using a multi- 
method approach that integrated qualitative methods to tell the NDP story from multiple perspectives and quantitative methods to assess and compare aspects that could be measured. Collectively, the 7 reports/articles in this supplement, listed in Table 1, explain the process, outcomes, lessons, and implications of the NDP.

The first report ${ }^{2}$ explains the multimethod approach required to evaluate the NDP. The use of both quantitative and qualitative methods in a clinical trial in which practices were randomized to facilitated and self-directed implementation approaches enabled an evolving intervention to be comprehensively assessed and understood in a changing environment. Ongoing feedback allowed the intervention team to adapt their approach to emerging insights.

The next report ${ }^{3}$ portrays how the NDP unfolded as seen by the independent evaluators. This article shows how the concept of a new model of practice, the personal medical home, changed as the TransforMED implementation organization, the PCMH movement, and the health care system evolved together during a turbulent time in American health care.

The third report ${ }^{4}$ examines the degree to which the wide range of NDP model components were implemented. This article also compares facilitated and self-directed practices on 3 practice-level outcomes: the proportion of the NDP model components implemented, the practices' capability to make and sustain change, and an aggregate measure of the patient's experience with the practice.

The fourth report ${ }^{5}$ brings to life the journeys experienced by the facilitated and self-directed practices during the NDP. This article uses case descriptions to explain variations in time, strategy, and resources that enabled or limited practice development.

\section{Table 1. Evaluation of the AAFP's First Patient-Centered Medical Home National Demonstration Project}

1. Jaén $C R$, Crabtree BF, Palmer RF, et al. Methods for evaluating practice change toward a patient-centered medical home. Ann Fam Med. 2010;8(Suppl 1):s9-s20.2

2. Stewart EE, Nutting PA, Crabtree BF, Stange KC, Miller WL, Jaén CR. Implementing the patient-centered medical home: observation and description of the National Demonstration Project. Ann Fam Med. 2010;8(Suppl 1):s21-s32. ${ }^{3}$

3. Nutting PA, Crabtree BF, Stewart EE, et al. Effect of facilitation on practice outcomes in the National Demonstration Project model of the patient-centered medical home. Ann Fam Med. 2010;8(Suppl 1):s33-s44. ${ }^{4}$

4. Nutting PA, Crabtree BF, Miller WL, Stewart EE, Stange KC, Jaén CR. Journey to the patient-centered medical home: a qualitative analysis of the experiences of practices in the National Demonstration Project. Ann Fam Med. 2010;8(Suppl 1):s45-s56.5

5. Jaén $C R$, Ferrer RL, Miller WL, et al. Patient outcomes at 26 months in the patient-centered medical home National Demonstration Project. Ann Fam Med. 2010;8(Suppl 1):s57-s67. ${ }^{6}$

6. Miller WL, Crabtree BF, Nutting PA, Stange KC, Jaén CR. Primary care practice development: a relationship-centered approach. Ann Fam Med. 2010;8(Suppl 1):s68-s79.7

7. Crabtree BF, Nutting PA, Miller WL, Stange KC, Stewart EE, Jaén CR. Summary of the National Demonstration Project and recommendations for the patient-centered medical home. Ann Fam Med. 2010;8(Suppl 1):s80-s90.8

AAFP = American Academy of Family Physicians.
The fifth report ${ }^{6}$ assesses the effect of the NDP intervention on patients and on the process of patient care. Two complementary categories of quality of care were assessed: patient report of multiple domains of their experience of health care and medical recordbased measures of care for specific conditions and cat-

The sixth report ${ }^{7}$ describes new ways of understanding and approaching the practice development ess. This article aims to provide insight for those

The closing report ${ }^{8}$ examines policy and practice implications of the NDP for those attempting to develop primary care and the health care system to improve health care, and ultimately the health, of the

The articles in this supplement, like the NDP itself, must be understood in context. This context includes the evolution of the PCMH concept and movement the roots of the NDP, and the value of and problems

\section{EVOLUTION OF THE PCMH CONCEPT} MOVEMENT

The $\mathrm{PCMH}$, like primary care, is rooted in the long and local knowledge of individuals, families, and munities.

Table 2 displays a time line of the evolution of the more recent $\mathrm{PCMH}$ concept and movement. The CMH is a political construct ${ }^{43}$ that includes new ways organizing and financing care, while attempting to proven value of primary care. ${ }^{44}$ The medical home idea began with the American Academy of Pediatrics' call for a model to organize the care of children with complex health care needs. ${ }^{19-22}$ The idea was taken up later by other medical organizations developing models of revitalized primary care. ${ }^{28,32,36}$ The PCMH continues to evolve in the context of other national movements calling for transformative changes in health care organization. ${ }^{27,45,46}$

A joint statement initially made by 4 medical professional organizations $^{35}$ that have been joined by a growing number of others ${ }^{36}$ articulates principles for the PCMH. These principles are summarized 
in the Supplemental Appendix, available online only, at

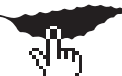
http://annfammed.org/cgi/content/full/8/suppl_1/ s2/DC1. The Patient-Centered Primary Care Collaborative ${ }^{36}$ has brought together partners from large national employers, primary care physician associations, health care benefits companies, and patient and health care quality associations to advocate for and advance the PCMH. Recent federal and state legislation also is promoting the $\mathrm{PCMH} .{ }^{47}$

Currently, hundreds of PCMH demonstration projects are being conducted around the country. ${ }^{36,40,41}$ Some of these projects include various attempts at different ways of paying for primary care for recognized $\mathrm{PCMH}$ practices or, on occasion, for particular components of the PCMH. ${ }^{48}$ Amidst a measurement/accountability culture and widely perceived need to control costs, a tool developed by National Committee on Quality Assurance (NCQA) ${ }^{37}$ has become the de facto standard for recognition as a PCMH, despite concerns about its focus on technical aspects of practice that can be easily measured ${ }^{49}$ and the potential for unintended consequences from implicitly devaluing relationship aspects of primary care that are essential but more difficult to measure..$^{1,44,50}$

\section{THE NDP IN CONTEXT}

In 2002, 7 national family medicine organizations launched the Future of Family Medicine Project with a goal to "develop a strategy to transform and renew the discipline of family medicine to meet the needs of patients in a changing health care environment." ${ }^{28(\mathrm{ps} 4)}$ Project participants conducted research, developed 7 reports, and acted on their recommendations. ${ }^{28,29,51-55}$ While reaffirming the "core values of continuing, comprehensive, compassionate, and personal care provided within the context of family and community,"28(ps11) a major focus of the project's research and policy development was a "New Model" of practice ${ }^{51}$ to accompany recommended health care system changes. The features of this new model ${ }^{51}$ emphasize a personal medical home that involves redesigned practices and can be seen online. ${ }^{28}$ The report also asserts that a "financially self-sustaining national resource will be implemented to provide practices with ongoing support in the transition to the New Model of family medicine." $28(\mathrm{ps} 4)$

In 2005, this new national resource was launched as a wholly-owned subsidiary of the American Academy of Family Physicians, called TransforMED. ${ }^{56}$ In the fall of that year, an invitation was widely distributed inviting family practices to participate in a national demonstration project of the "New Model" of family medicine. In March 2006, 36 participating practices were announced and randomized to facilitated and selfdirected intervention groups. In June 2006, the NDP project began. Its focus was on assessing the ability of practices to make transformative changes with help from a TransforMED facilitator or on their own. This project did not include payment reform, 1 of the 7 principles of the PCMH (Supplemental Appendix).

The authors of the current article were engaged early in this process as an independent evaluation team, funded by the American Academy of Family

\section{Table 2. A Brief History of the Patient-Centered Medical Home}

$\mathrm{AAP}=$ American Academy of Pediatrics; AAFP $=$ American Academy of Family Physicians; $\mathrm{ACP}=$ American College of Physicians; $\mathrm{AOA}=$ American Osteopathic Association; $\mathrm{NCQA}=$ National Committee on Quality Assurance; $\mathrm{NDP}=$ National Demonstration Project; $\mathrm{PCMH}=$ patient-centered medical home; $\mathrm{WHO}=$ World Health Organization. 
Physicians and The Commonwealth Fund, and with the authority to publish findings without prior review by the sponsors. Using the methods overviewed by Jaén et $\mathrm{al}_{1}{ }^{2}$ we embarked on describing the process, outcome, and lessons of the NDP, and provided early insights from ongoing analyses to TransforMED, to inform the continued evolution of their work with practices. A previous report shared early lessons with the larger health care community. ${ }^{1}$

\section{WHAT IS VALUABLE AND WHAT IS PROBLEMATIC ABOUT FAMILY MEDICINE AND PRIMARY CARE}

Health care systems based on primary care have better quality, ${ }^{57}$ lower cost, ${ }^{57-59}$ less inequality in health care and health, ${ }^{25,38,60-63}$ and better population health. ${ }^{25,59,64}$ These attributes of primary care emerge from synergy among the following factors, known as the 4 pillars of

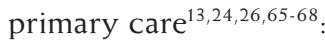

- Easy access to first-contact care: accessibility as the first contact of patients with the health care system

- Comprehensive care: accountability for addressing a large majority of personal health care needs

- Coordination of care: integration and coordination of care in different settings, and across different domains that include acute and (often comorbid) chronic illnesses, mental health, disease prevention, and health promotion-guiding access to more narrowly focused care when needed

- Personal relationship over time: sustained partnership and personal relationship over time, with patients known in the context of their family and community (also known as continuity)

Among the many dysfunctions of the US health care system ${ }^{27}$ is its lack of focus on primary care. ${ }^{69-71}$ This devaluing of primary care has reduced its effectiveness to the point where the need for fundamental change is widely recognized. ${ }^{72,73}$ As others have noted, change is needed both within the primary care enterprise $^{28}$ and in the larger system in which it is embedded. ${ }^{28,70,74}$

Primary care is the canary in the mine of the broken US health care system. ${ }^{65}$ Although there are hopeful exceptions, ${ }^{17,75-77}$ the current payment system ${ }^{78,79}$ and (mis)conceptualizations about what represents quality in primary care ${ }^{66-68,80,81}$ have engendered what has been called a hamster-on-a-wheel approach to care. ${ }^{82,83}$ In this fragmented health care environment, ${ }^{81}$ the focus of primary care has been distracted from the fundamental need for relationships with patients, communities, and other parts of the health care system. ${ }^{84,85}$ Primary care increasingly has narrowed the scope and place of its care, and diminished its availability at the times of patients' greatest need ${ }^{86-88}$ In addition, primary care often has been physician- and practice-centric in its approach, and has not sufficiently used technology, a team approach, and patient enablement to foster access, integration of care, and development of relationships. ${ }^{89-94}$ These are among the problems that the "New Model" and the PCMH are intended to resolve.

\section{A WAY FORWARD}

The articles in this supplement demonstrate that it is possible for highly motivated, largely independent practices $^{3}$ to implement most of the predominantly technological components of the $\mathrm{PCMH} .{ }^{4}$ This implementation results in improved indicators of chronic disease care as assessed from medical records, but at the cost of reducing the quality of key attributes of primary care as rated by patients, at least over the 26 months of the NDP.4, 6 The project's multimethod evaluation ${ }^{2}$ also shows that understanding the process of developing practices' internal capabilities is critical to successfully managing change. ${ }^{5,7}$ As the PCMH continues to evolve, both practice and system reforms are needed to make it easier to integrate, personalize, and prioritize care for whole people, communities, and populations. $^{8}$

To read or post commentaries in response to this article, see it online at http://www.annfammed.org/cgi/content/full/8I suppl_1/s2.

Key words: Primary care; family practice; National Demonstration Project; organizational change; quality improvement; patient-centered medical home; patient-centered care; practice-based research

Submitted January 8, 2010; submitted, revised, February 11, 2010; accepted March 1, 2010.

Author affiliations: Departments of Family Medicine, Epidemiology $\mathcal{E}$ Biostatistics, and Sociology, and The Case Comprehensive Cancer Center, Case Western Reserve University, Cleveland, Ohio (Stange); Department of Family Medicine, Lehigh Valley Health Network, Allentown; and Department of Family and Community Medicine, Pennsylvania State College of Medicine, Hershey, Pennsylvania (Miller); Center for Research Strategies, Denver, Colorado, and Department of Family Medicine, University of Colorado Health Sciences Center, Aurora, Colorado (Nutting); Department of Family Medicine, Robert Wood Johnson Medical School, University of Medicine \& Dentistry of New Jersey, New Brunswick; Department of Epidemiology, School of Public Health, University of Medicine \& Dentistry of New Jersey, Piscataway; and Cancer Institute of New Jersey, New Brunswick, New Jersey (Crabtree); National Research Network, American Academy of Family Physicians, Leawood, Kansas (at the time of the project, Department of Family and Community Medicine, University of Texas Health Science Center at San Antonio) (Stewart); Departments of Family \& Community Medicine, and of Epidemiology $\&$ Biostatistics, University of Texas Health Science Center at San Antonio, San Antonio, Texas (Jaén). 
Disclaimer: Drs Stange and Nutting, who are editors of the Annals, were not involved in the editorial evaluation of or decision to publish this article.

Funding support: The independent evaluation of the National Demonstration Project (NDP) practices was supported by the American Academy of Family Physicians (AAFP) and The Commonwealth Fund. The Commonwealth Fund is a national, private foundation based in New York City that supports independent research on health care issues and makes grants to improve health care practice and policy.

Publication of the journal supplement is supported by the American Academy of Family Physicians Foundation, the Society of Teachers of Family Medicine Foundation, the American Board of Family Medicine Foundation, and The Commonwealth Fund.

Dr Stange's time was supported in part by a Clinical Research Professorship from the American Cancer Society.

Disclaimer: The views presented here are those of the authors and not necessarily those of The Commonwealth Fund, its directors, officers, or staff.

Acknowledgments: The NDP was designed and implemented by TransforMED, LLC, a wholly-owned subsidiary of the AAFP. We are indebted to the participants in the NDP and to TransforMED for their tireless work. We also are grateful to the practices and people that participated in the NDP.

In the facilitated group: Bay Crossing Family Medicine, Annapolis, Maryland; Central Oregon Family Medicine, PC, Redmond, Oregon Cranford Family Practice, Cranford, New Jersey; Family Health Center of Joplin, Inc, Joplin, Missouri; Family Medicine, Geriatrics and Wellness, Lower Gwynedd, Pennsylvania; Family Practice Partners, Murfreesboro, Tennessee; Harbor of Health, Memphis, Tennessee; Hays Family Medicine, Hays, Kansas; Indian Land Primary Care, Indian Land, South Carolina; James J. Meyer, MD, PC, Littleton, Colorado; LifeScape Medical Associates, Scottsdale, Arizona; MHS Primary Care, Inc, Cromwell Family Practice, Cromwell, Connecticut; Myrtue Medical Center, Harlan, lowa; Stephen J. Veit, MD, PC, Cherokee, lowa; Trinity Clinic-Whitehouse, Whitehouse, Texas; Westshore Family Medicine, Muskegon, Michigan; and Wood River Family Medicine Clinic, Hailey, Idaho.

In the self-directed group: DHMC, Community Health Center, Lebanon, New Hampshire; Carondelet Medical Group, Tucson, Arizona; Crossroads Family Practice, North Garden, Virginia; Duncan Medical Associates, PC, Duncan, Oklahoma; Harborwood Family Medicine at the Lakes, Muskegon, Michigan; Henry County Family Physicians, Inc, Napoleon, Ohio; Kollman Clinic, Inc, Dover, Ohio; Lifetime Family Medicine, Haymarket, Virginia; Neil A. Patterson, MD, PA, Oviedo, Florida; Olio Road Family Care, Fishers, Indiana; Piedmont Family Care, Piedmont, Oklahoma; Romeo Medical Clinic, Turlock, California; Seaport Family Practice, Belfast, Maine; and Sommerville Family Practice, PC, Midlothian, Virginia.

\section{References}

1. Nutting PA, Miller WL, Crabtree BF, Jaén CR, Stewart EE, Stange KC. Initial lessons from the first national demonstration project on practice transformation to a patient-centered medical home. Ann Fam Med. 2009;7(3):s54-s60.

2. Jaén $C R$, Crabtree BF, Palmer RF, et al. Methods for evaluating practice change toward a patient-centered medical home. Ann Fam Med. 2010;8(Suppl 1):s9-s20.
3. Stewart EE, Nutting PA, Crabtree BF, Stange KC, Miller WL, Jaén CR. Implementing the patient-centered medical home: observation and description of the National Demonstration Project. Ann Fam Med. 2010;8(Suppl 1):s21-s32.

4. Nutting PA, Crabtree BF, Stewart EE, et al. Effect of facilitation on practice outcomes in the National Demonstration Project model of the patient-centered medical home. Ann Fam Med. 2010;8(Suppl 1): s33-s44.

5. Nutting PA, Crabtree BF, Miller WL, Stewart EE, Stange KC, Jaén $C R$. Journey to the patient-centered medical home: a qualitative analysis of the experiences of practices in the National Demonstration Project. Ann Fam Med. 2010;8(Suppl 1):s45-s56.

6. Jaén $C R$, Ferrer RL, Miller WL, et al. Patient outcomes at 26 months in the patient-centered medical home National Demonstration Project. Ann Fam Med. 2010;8(Suppl 1):s57-s67.

7. Miller WL, Crabtree BF, Nutting PA, Stange KC, Jaén CR. Primary care practice development: a relationship-centered approach. Ann Fam Med. 2010;8(Suppl 1):s68-s79.

8. Crabtree BF, Nutting PA, Miller WL, Stange KC, Stewart EE, Jaén CR. Summary of the National Demonstration Project and recommendations for the patient-centered medical home. Ann Fam Med. 2010;8(Suppl 1):s80-s90x.

9. Berger J, Mohr J. A Fortunate Man: The Story of a Country Doctor. New York, NY: Rinehart and Winston; 1967.

10. McWhinney IR. Beyond diagnosis: an approach to the integration of behavioral science and clinical medicine. $N$ Engl J Med. 1972;287(8):384-387.

11. McWhinney IR. The naturalist tradition in general practice. J Fam Pract. 1977;5(3):375-378.

12. McWhinney IR. Primary care: core values. Core values in a changing world. BMJ. 1998;316(7147):1807-1809.

13. McWhinney IR, Freeman T. Textbook of Family Medicine. 3rd ed. New York, NY: Oxford University Press; 2009.

14. Pickles W. Epidemiology in Country Practice. Baltimore, MD: Williams \& Wilkins; 1939

15. Stephens GG. The Intellectual Basis of Family Practice. Tucson, AZ: Winter Publishing Company; 1982.

16. Loxterkamp D. Being there: on the place of the family physician. J Am Board Fam Pract. 1991;4(5):354-360.

17. Loxterkamp D. A Measure of My Days: The Journal of a Country Doctor. Hanover, NH: University Press of New England; 1997.

18. Fábrega H Jr. Evolution of Sickness and Healing. Berkeley, CA: University of California Press; 1998.

19. Medical Home Initiatives for Children With Special Needs Project Advisory Committee. American Academy of Pediatrics. The medical home. Pediatrics. 2002;110(1, pt 1):184-186.

20. Hughes JR, Grayson R, Stiles FC. Fragmentation of care and the medical home. Pediatrics. 1977;60(4):559.

21. Malouin RA, Turner J. A review of the evidence for the medical home for children with special health care needs. Pediatrics. 2009;123(2):e369.

22. Sia C, Tonniges TF, Osterhus E, Taba S. History of the medical home concept. Pediatrics. 2004;113(5 Suppl):1473-1478

23. Starfield B. Primary Care: Concept, Evaluation, and Policy. New York, NY: Oxford University Press; 1992.

24. Starfield B. Primary Care: Balancing Health Needs, Services, and Technology. Rev ed. New York, NY: Oxford University Press; 1998.

25. Starfield B, Shi LY, Macinko J. Contribution of primary care to health systems and health. Milbank Q. 2005;83(3):457-502.

26. Donaldson MS, Yordy KD, Lohr KN, Vanselow NA, eds. Primary Care: America's Health in a New Era. Washington, DC: National Academy Press; 1996. 
27. Institute of Medicine. Committee on Quality of Health Care in America. Crossing the Quality Chasm: A New Health System for the 21st Century. Washington, DC: National Academy Press; 2001.

28. Martin JC, Avant RF, Bowman MA, et al; Future of Family Medicine Project Leadership Committee. The future of family medicine: a collaborative project of the family medicine community. Ann Fam Med. 2004;2(Suppl 1):S3-S32.

29. Bucholtz JR, Matheny SC, Pugno PA, David A, Bliss EB, Korin EC. Task Force Report 2. Report of the task force on medical education. Ann Fam Med. 2004;2(Suppl 1):S51-S64.

30. TransforMED. The TransforMED patient-centered model. http:// www.transformed.com/transformed.cfm. Accessed Sep 7, 2009.

31. Davis K, Schoenbaum SC, Audet AM. A 2020 vision of patient-centered primary care. J Gen Intern Med. 2005;20(10):953-957.

32. American College of Physicians (ACP). The advanced medical home: a patient-centered, physician-guided model of health care. 2006 http://www.acponline.org/advocacy/where_we_stand/policy/adv_ med.pdf. Accessed Jul 5, 2009.

33. Chokshi DA. Ensuring progress in primary care-what can health care reform realistically accomplish? N Engl J Med. 2009;361(20): e43.

34. TransforMED. National Demonstration Project 2008. http://www. transformed.com/ndp.cfm. Accessed May 3, 2010.

35. American Academy of Family Physicians (AAFP), American Academy of Pediatrics (AAP), American College of Physicians (ACP), American Osteopathic Association (AOA). Joint principles of the patient-centered medical home. February 2007. http://www.aafp.org/pcmh/ principles.pdf. Accessed May 3, 2010.

36. Patient-Centered Primary Care Collaborative. Web site. http://www. pcpcc.net/. Accessed Feb 2, 2009.

37. National Committee on Quality Assurance (NCQA). Physician Practice Connections-Patient-Centered Medical Home. 2008. http:// www.ncqa.org/tabid/631/Default.aspx. Accessed May 3, 2010.

38. Chan M. Primary health care as a route to health security. Lancet. 2009;373(9675):1586-1587.

39. Chan M. Return to Alma-Ata. Lancet. 2008;372(9642):865-866.

40. Crosby JB, Grundy P, Rogers E, Patient Centered Primary Care Collaborative. Proof in Practice. A Compilation of Patient Centered Medical Home Pilot and Demonstration Projects. Washington, DC: National Committee for Quality Assurance; 2008. http://www.pcpcc.net/files/ PilotGuidePip_0.pdf. Accessed May 3, 2010.

41. Sugarman J. Medical Home Digest. New York, NY: Commonwealth Fund; 2009.

42. Larson EB. Group Health Cooperative-one coverage-and-delivery model for accountable care. N Engl J Med. 2009;361(17):1620-1622.

43. Robert Graham Center. The Patient Centered Medical Home: history, seven core features, evidence and transformational change. 2007. http://www.graham-center.org/online/graham/home/publications/ monographs-books/2007/rgcmo-medical-home.html. Accessed Mar 12, 2010.

44. Stange KC, Nutting PA, Miller WL, et al. Defining and measuring the patient-centered medical home. J Gen Intern Med. 2010;25(6) 601-612.

45. Institute of Medicine. Unequal Treatment: Confronting Racial and Ethnic Disparities in Healthcare. Washington, DC: The National Academies Press; 2003.

46. Institute of Medicine. Insuring America's Health: Principles and Recommendations. Washington, DC: National Academies Press; 2004.

47. Patient-Centered Primary Care Collaborative. Legislative Issues. 2009. http://www.pcpcc.net/content/legislative. Accessed Jan 3, 2010.

48. Berenson RA, Rich EC. How to buy a medical home? Policy options and practical questions. J Gen Intern Med. 2010;25(6):619-624.
49. National Committee on Quality Assurance (NCQA). Planned Evolution of PPC-PCMH Requirements. 2009. http://ncqa.org/tabid/631/ Default.aspx. Accessed Jun 15, 2009.

50. O'Malley AS, Peikes D, Ginsburg PB. Qualifying a physician practice as a medical home. Policy Perspective: Insights into Health Policy Issues. No. 1, December 2008. http://www.hschange.com/ CONTENT/1030/\#ib1. Accessed Jul 8, 2009.

51. Task Force 1 Writing Group, Green A, Graham R, et al. Task Force 1. Report of the task force on patient expectations, core values, reintegration, and the new model of family medicine. Ann Fam Med. 2004;2(Suppl 1):s33-s50.

52. Jones WA, Avant RF, Davis N, Saultz J, Lyons P. Task Force Report 3. Report of the task force on continuous personal, professional, and practice development in family medicine. Ann Fam Med. 2004;2(Suppl 1):s65-s74.

53. Dickinson JC, Evans KL, Carter J, Burke K. Task Force Report 4. Report of the task force on marketing and communications. Ann Fam Med. 2004;2(Suppl 1):s75-s87.

54. Roberts RG, Snape PS, Burke K. Task Force Report 5. Report of the task force on family medicine's role in shaping the future health care delivery system. Ann Fam Med. 2004;2(Suppl 1):s88-s99.

55. Spann SJ; Task Force 6 and the Executive Editorial Team. Report on financing the new model of family medicine. Ann Fam Med. 2004;2(Suppl 3):s1-s21.

56. TransforMED. TransforMED - Transforming medical practices. http:// www.transformed.com/. Accessed Jan 3, 2010.

57. Baicker K, Chandra A. Medicare spending, the physician workforce, and beneficiaries' quality of care. Health Aff (Millwood). 2004;(Supp Web Exclusives):W184-W197.

58. Greenfield S, Nelson EC, Zubkoff M, et al. Variations in resource utilization among medical specialties and systems of care. Results from the medical outcomes study. JAMA. 1992;267(12):1624-1630.

59. Lewin S, Lavis JN, Oxman AD, et al. Supporting the delivery of cost-effective interventions in primary health-care systems in lowincome and middle-income countries: an overview of systematic reviews. Lancet. 2008;372(9642):928-939.

60. Starfield B. Primary care and equity in health: the importance to effectiveness and equity of responsiveness to people's needs. Humanity Soc. 2009;33(1E2):56-73

61. Rohde J, Cousens S, Chopra M, et al. 30 years after Alma-Ata: has primary health care worked in countries? Lancet. 2008;372(9642): 950-961.

62. Ferrer RL. Pursuing equity: contact with primary care and specialist clinicians by demographics, insurance, and health status. Ann Fam Med. 2007;5(6):492-502.

63. Beal AC, Doty MM, Hernandez SE, Shea KK, Davis K. Closing the divide: how medical homes promote equity in health care: results from The Commonwealth Fund 2006 health care quality survey. 2007. http://www.commonwealthfund.org/Content/Publications/ Fund-Reports/2007/Jun/Closing-the-Divide--How-Medical-HomesPromote-Equity-in-Health-Care--Results-From-The-CommonwealthF.aspx. Accessed Jun 13, 2009.

64. Starfield B, Shi L, Grover A, Macinko J. The effects of specialist supply on populations' health: assessing the evidence. Health Aff (Millwood). 2005;(Suppl Web Exclusives):W5-97-W5-107.

65. Stange KC, Jaén CR, Flocke SA, Miller WL, Crabtree BF, Zyzanski SJ. The value of a family physician. J Fam Pract. 1998;46(5):363-368.

66. Stange KC. A science of connectedness. Ann Fam Med. 2009; $7(5): 387-395$

67. Stange KC. The generalist approach. Ann Fam Med. 2009;7(3) 198-203.

68. Stange KC, Ferrer RL. The paradox of primary care. Ann Fam Med. 2009;7(4):293-299. 
69. Starfield B. Is US health really the best in the world? JAMA. 2000; 284(4):483-485.

70. Sandy LG, Bodenheimer T, Pawlson LG, Starfield B. The political economy of U.S. primary care. Health Aff (Millwood). 2009;28(4): 1136-1145.

71. Geyman JP. Health Care in America: Can Our Ailing System be Healed? Boston, MA: Butterworth-Heinemann; 2002.

72. Bodenheimer T. Primary care-will it survive? N Engl J Med. 2006; 355(9):861-864.

73. Bodenheimer T, Grumbach K, Berenson RA. A lifeline for primary care. N Engl J Med. 2009;360(26):2693-2696.

74. Fisher ES. Building a medical neighborhood for the medical home. N Engl J Med. 2008;359(12):1202-1205.

75. Mullan F. Big Doctoring in America: Profiles in Primary Care. Berkeley, CA: University of California Press; 2002.

76. Aarendonk D, De Maeseneer J. Quality in Primary Care: official journal of the European Forum for Primary Care. Qual Prim Care. 2008;16(3):145-146.

77. Solberg LI, Hroscikoski MC, Sperl-Hillen JM, Harper PG, Crabtree BF. Transforming medical care: case study of an exemplary, small medical group. Ann Fam Med. 2006;4(2):109-116.

78. Goroll AH, Berenson RA, Schoenbaum SC, Gardner LB. Fundamental reform of payment for adult primary care: comprehensive payment for comprehensive care. J Gen Intern Med. 2007;22(3):410-415

79. Goroll AH. The future of primary care: reforming physician payment. N Engl J Med. 2008;359(20):2087, 2090

80. Heath I, Rubenstein A, Stange KC, van Driel M. Quality in primary health care: a multidimensional approach to complexity. BMJ. 2009; 338:b1242.

81. Stange KC. The problem of fragmentation and the need for integrative solutions. Ann Fam Med. 2009;7(2):100-103.
82. Berger E. The patient-centered medical home: a solution to "hamster health care" or a drain on emergency care? Ann Emerg Med. 2008;52(6):654-657.

83. Morrison I, Smith R. Hamster health care. BMJ. 2000;321(7276): 1541-1542.

84. Starfield B. New paradigms for quality in primary care. $\mathrm{Br} / \mathrm{Gen}$ Pract. 2001;51(465):303-309.

85. Loxterkamp D, Kazal LA Jr. Changing horses midstream: the promise and prudence of practice redesign. Ann Fam Med. 2008;6(2):167-170.

86. American College of Physicians. The Impending Collapse of Primary Care Medicine and Its Implications for the State of the Nation's Health Care: A Report From the American College of Physicians. Philadelphia, PA: ACP; 2006.

87. Sandy LG, Schroeder SA. Primary care in a new era: disillusion and dissolution? Ann Intern Med. 2003;138(3):262-267.

88. Loxterkamp D. Border crossings: on the boundary of the physicianpatient relationship. J Am Board Fam Pract. 1998;11(6):487-489.

89. Bodenheimer T, Grumbach K. Improving Primary Care: Strategies and Tools for a Better Practice. New York, NY: Lange Medical Books/ McGraw-Hill; 2007.

90. Geyman JP, Hart LG. Primary care at a crossroads: progress, problems, and future projections. J Am Board Fam Pract. 1994;7(1):60-70.

91. Showstack J, Rothman AA, Hassmiller SB, eds. The Future of Primary Care. San Francisco, CA: Jossey-Bass; 2004.

92. Safran DG. Defining the future of primary care: what can we learn from patients? Ann Intern Med. 2003;138(3):248-255.

93. Hsu C, Phillips WR, Sherman KJ, Hawkes R, Cherkin DC. Healing in primary care: a vision shared by patients, physicians, nurses, and clinical staff. Ann Fam Med. 2008;6(4):307-314.

94. Loxterkamp D. Benefits of continuity of care. Fam Med. 2009; 41(5):312. 